\title{
Dotacje na prace konserwatorskie, restauratorskie lub roboty budowlane przy zabytkach wpisanych do rejestru zabytków na przykładzie powiatu włocławskiego
}

\author{
Subsidies for Maintenance, Restoration and Building Works \\ of Monuments Registered in the Monuments Record on the \\ Territory of the Włocławek District
}

Streszczenie. Art. 81 ust. 1 ustawy z dnia 23 lipca 2003 r. o ochronie zabytków i opiece nad zabytkami pozwala organowi stanowiącemu gminy, powiatu lub samorządu województwa, na zasadach określonych w podjętej przez ten organ uchwale, udzielanie dotacji na prace konserwatorskie, restauratorskie lub roboty budowlane przy zabytku wpisanym do rejestru. Celem niniejszego artykułu jest przybliżenie tematyki „dotacji zabytkowych” na przykładzie powiatu włocławskiego. W opracowaniu przedstawiono zasady udzielania dotacji na prace konserwatorskie, restauratorskie lub roboty budowlane przy zabytkach wpisanych do rejestru zabytków na obszarze powiatu włocławskiego oraz przedstawione zostały informacje na temat udzielanych dotacji przez powiat włocławski w latach 20122013. 
Słowa kluczowe: dotacje; samorząd powiatowy; zabytki.

\begin{abstract}
Art. 81 item 1 of the Historic Monuments Preservation Act of 23. July 2003 allows the legislative body of a gmina, poviat or the voivodeship government, according to the principles determined in the resolution passed by that body, to give subsidies for the maintenance, restoration or construction works of monuments registered in the monument record. The aim of this article is to present the issue of "subsidies for historic monuments" on the example of the Włocławek poviat. The study presents the principles of granting subsidies for the maintenance, restoration and construction works of monuments registered in the monument record within the territory of the Włocławek poviat and the information on subsidies granted by the Włocławek poviat in years 2012-2013.
\end{abstract}

Keywords: subsidies; poviat government; historic monuments.

\title{
1. Wprowadzenie
}

Zgodnie z art. 4 ust. 1 pkt 7 ustawy z dnia 5 czerwca 1998 r. o samorządzie powiatowym ${ }^{1}$ powiat wykonuje określone ustawami zadania publiczne o charakterze ponadgminnym w zakresie kultury oraz ochrony zabytków i opieki nad zabytkami. Art. 81 ust. 1 ustawy z dnia 23 lipca 2003 r. o ochronie zabytków i opiece nad zabytkami ${ }^{2}$ stanowi, że w trybie określonym odrębnymi przepisami dotacja na prace konserwatorskie, restauratorskie lub roboty budowlane przy zabytku wpisanym do rejestru może być udzielona przez organ stanowiący gminy, powiatu lub samorządu województwa, na zasadach określonych w podjętej przez ten organ uchwale. Uchwała dotacyjna powinna określać zasady postępowania w sprawie udzielania dotacji, sposób jej rozliczania oraz kontroli wykonania zadania, na które przekazano środki finansowe w formie dotacji celowej $^{3}$.

Tekst jedn. Dz.U. z 2013 r., poz. 595.

Dz.U. z 2003 r. Nr 162, poz. 1568 ze zm.

M. Tyniewicki, Kompetencje organów jednostek samorzqdu terytorialnego w zakresie ustanawiania i udzielania dotacji celowych, [w:] A. Borodo (red.), Dotacje i subwencje w systemie finansowym samorzq̨du terytorialnego, Toruń 2013, s. 153. 
Organ stanowiący jednostki samorządu terytorialnego jako normodawca w pierwszej kolejności podejmuje uchwałę określającą zasady dotowania, a następnie po przeprowadzeniu przez organ wykonawczy zgodnie z powyższą uchwałą procedury przyjmowania i weryfikacji wniosków o udzielenie dotacji, będzie podmiotem wydającym indywidualne decyzje ${ }^{4}$. Ważną kwestią jest również zabezpieczenie w uchwale budżetowej środków finansowych na udzielenie tego typu dotacji.

Uchwała budżetowa kształtuje strukturę planów dochodów i wydatków w odpowiedniej szczegółowości klasyfikacji budżetowej. W uchwale tej wyróżniane są również planowane wydatki w formie dotacji celowych $^{5}$. Zgodnie z art. 214 pkt 1 ustawy z dnia 27 sierpnia 2009 r. o finansach publicznych ${ }^{6}$ istnieje obowiązek opracowywania załącznika do uchwały budżetowej, zawierającego zestawienie dotacji udzielanych z budżetu jednostki samorządu terytorialnego z podziałem na dotowane jednostki w ramach sektora finansów publicznych oraz spoza tego sektora, także z wyodrębnieniem rodzajów dotacji, tj.: przedmiotowych, podmiotowych oraz celowych związanych z realizacją zadań jednostek samorządu terytorialnego. W załączniku tym kwoty dotacji powinny być przypisane poszczególnym numerom podziałek klasyfikacji budżetowej. Załącznik dotacyjny stanowi konsekwencję tego typu wydatków ujętych w planie wydatków, co umożliwia weryfikację kwot dotacji z tym planem $^{7}$. Służy to realizacji zasady jawności i przejrzystości budżetu, która gwarantuje m.in. podawanie do publicznej wiadomości kwot dotacji udzielanych z budżetu jednostki samorządu terytorialnego ${ }^{8}$.

Konstruując przepisy uchwały określającej zasady dotowania, należy mieć również na uwadze uchwałę Kolegium Regionalnej Izby Obrachun-

4 J.M. Salachna, Granice samodzielności legislacyjnej jednostek samorzqdu terytorialnego. Studium prawnofinansowe na gruncie ustrojowym, Gdańsk 2012, s. 257-258.

5 C. Kosikowski, E, Ruśkowski, Finanse publiczne i prawo finansowe, Warszawa 2008, s. 365.

$6 \quad$ Tekst jedn. Dz.U. z 2013 r., poz. 885 ze zm.

7 A. Gorgol, Zakres budżetu jednostki samorzqdu terytorialnego, [w:] E. Ruśkowski, J.M. Salachna (red.), Nowa ustawa o finansach publicznych wraz z ustawq wprowadzajqca. Komentarz praktyczny, Gdańsk 2010, s. 658.

8 W. Wójtowicz, Zasady publicznej gospodarki finansowej [w:] W. Wójtowicz (red.), Zarys finansów publicznych i prawa finansowego, Warszawa 2008, s. 40. 
kowej w Zielonej Górze z dnia 13 lutego 2008 r. ${ }^{9}$, z której wynika, że zadaniem organu stanowiącego jest podjęcie nie tylko uchwały generalnej określającej zasady przyznawania dotacji, ale również uchwały indywidualnej o przyznaniu dofinansowania konkretnemu podmiotowi. Po pierwsze, niedopuszczalne jest zamieszczenie tych postanowień w jednej uchwale. Po drugie, skoro kompetencje w zakresie przyznania i ustalenia wysokości dotacji należą do organu stanowiącego, to niedopuszczalne jest ich przeniesienie na organ wykonawczy. Zadaniem organu wykonawczego jest jedynie zebranie wniosków, formalne ich sprawdzenie i przedstawienie radzie lub sejmikowi.

Celem niniejszego opracowania jest zatem określenie (na przykładzie powiatu włocławskiego), w jaki sposób organ stanowiący jednostki samorządu terytorialnego powinien przeprowadzać procedurę prawną związaną z opracowaniem zasad udzielania dotacji oraz przekazywania jej konkretnym beneficjentom. Jednocześnie artykuł wskazuje na problem niskiej liczby składanych wniosków o udzielenie dotacji mimo możliwości uzyskania jej z budżetu powiatu włocławskiego.

\section{Uchwała Rady Powiatu we Włocławku w sprawie dotacji „zabytkowej”}

Według art. 12 pkt 11 ustawy o samorządzie powiatowym do wyłącznej właściwości Rady Powiatu należy podejmowanie uchwał w innych sprawach zastrzeżonych ustawami do kompetencji Rady Powiatu. Na tej podstawie Rada Powiatu we Włocławku w dniu 30 sierpnia 2012 r. podjęła uchwałę nr XV/166/12 w sprawie określenia zasad udzielania dotacji na prace konserwatorskie, restauratorskie lub roboty budowlane przy zabytkach wpisanych do rejestru zabytków na obszarze powiatu włocławskiego $^{10}$, które stanowią załącznik nr 1 do niniejszej uchwały. Zasady te zosta-

\footnotetext{
9 http://www.bip.zielonagora.rio.gov.pl/dok_uchwaly/0540805033.pdf (dostęp: 5 grudnia 2013 r.).

10 Dz.Urz. Woj. Kujawsko-Pomorskiego z 2012 r., poz. 1876.
} 
ły zmienione uchwałą nr XXIII/243/13 ${ }^{11}$ podczas sesji Rady Powiatu we Włocławku w dniu 17 czerwca $2013 \mathrm{r}$.

Zgodnie z §1 ww. zasad celem dotacji jest ochrona krajobrazu kulturowego i dziedzictwa narodowego na terenie powiatu włocławskiego, wspieranie i uzupełnianie działań właścicieli i zarządców zabytków dla zapewnienia ochrony i konserwacji wartościowych elementów substancji zabytkowej. Jak stanowi §2 ust. 1, dotacje mogą być udzielane na wykonanie prac konserwatorskich, restauratorskich i robót budowlanych przy zabytkach wpisanych do rejestru zabytków, położonych na obszarze powiatu. Na podstawie §2 ust. 2 dotacja może być udzielona na wykonanie powyższych prac, które wnioskodawca zamierza wykonać w roku następnym po złożeniu wniosku, z takim zastrzeżeniem, że wnioski składa się do 30 września roku poprzedzającego rok, w którym planowane jest rozpoczęcie prac określonych we wniosku. W przypadku niewykorzystania w całości środków przeznaczonych w budżecie powiatu na dotacje lub ich zwiększenia w ciągu roku budżetowego, wnioski o dotacje mogą być składane w drugim terminie, tj. do 31 lipca roku, w którym dotacja ma być wykorzystana na wykonanie prac określonych we wniosku. Informację o możliwości składania wniosków w drugim terminie zarząd powiatu podaje do publicznej wiadomości na stronie internetowej powiatu włocławskiego oraz w dzienniku o zasięgu lokalnym najpóźniej do 15 lipca każdego roku, w którym taka możliwość wystąpi. Formularz wniosku stanowi załącznik do tych zasad. W pierwszej wersji omawianych zasadach wnioski o udzielanie dotacji miały być składane do10 października roku poprzedzającego rok, w którym planowano je wykorzystać. Wyjątkiem był rok 2012 (w którym uchwalono zasady), ponieważ wtedy wnioski składano w terminie 15 dni od dnia wejścia w życie zasad.

Zgodnie z § 3 dotacja może być udzielona osobie fizycznej, osobie prawnej lub jednostce organizacyjnej posiadającej tytuł prawny do zabytku, wynikający z prawa własności, użytkowania wieczystego, trwałego zarządu, ograniczonego prawa rzeczowego, albo stosunku zobowiązaniowego. §4 stanowi, że wysokość środków przeznaczonych na dotacje usta-

11 Dz.Urz. Woj. Kujawsko-Pomorskiego z 2013 r., poz. 2261. 
lana jest w budżecie powiatu. Według kolejnego paragrafu omawianych zasad dotacja może być udzielona w wysokości do 50\% nakładów koniecznych na wykonanie prac konserwatorskich, restauratorskich lub robót budowlanych przy zabytku wpisanym do rejestru. Łączna wysokość dotacji na prace konserwatorskie, restauratorskie lub roboty budowlane przy zabytku udzielonych przez samorząd powiatowy, inne jednostki samorządu terytorialnego, ministra właściwego do spraw kultury i dziedzictwa narodowego, wojewódzkiego konserwatora zabytków bądź środków uzyskiwanych z innych źródeł nie może przekroczyć 100\% wysokości nakładów koniecznych na wykonanie tych prac lub robót. Paragraf ten zastrzega, że udzielona dotacja celowa na prace konserwatorskie, restauratorskie lub roboty budowlane przy zabytkach wpisanych do rejestru zabytków położonych na terenie powiatu włocławskiego nie może być wykorzystywana na:

1. sfinansowanie kosztów nadzoru,

2. podatek VAT, jeżeli nie stanowi on kosztu u wnioskodawcy,

3. opłaty związane z uzyskaniem pozwoleń i decyzji administracyjnych,

4. odszkodowania, administracyjne kary pieniężne, kary umowne wraz z odsetkami, koszty postępowania sądowego i egzekucyjnego,

5. koszty wynagrodzeń pracowników podmiotów składających wniosek o dotacje.

\section{Procedura przyznawania dotacji „zabytkowej” w Powiecie Włocławskim}

W świetle $\S 6$ ust. 4 zasad udzielania dotacji na prace konserwatorskie, restauratorskie lub roboty budowlane przy zabytkach wpisanych do rejestru zabytków na obszarze powiatu włocławskiego o dacie złożenia wniosku decyduje data jego wpływu do Starostwa Powiatowego we Włocławku. Zgodnie zaś z $\S 6$ ust. 5 złożenie wniosku o dotację nie jest równoznaczne z przyznaniem dotacji, nie gwarantuje również przyznania dotacji w wysokości wnioskowanej przez składającego wniosek. Według §7 ust. 1 wniosek o przyznanie dotacji należy złożyć na formularzu, który winien zawierać w szczególności: 


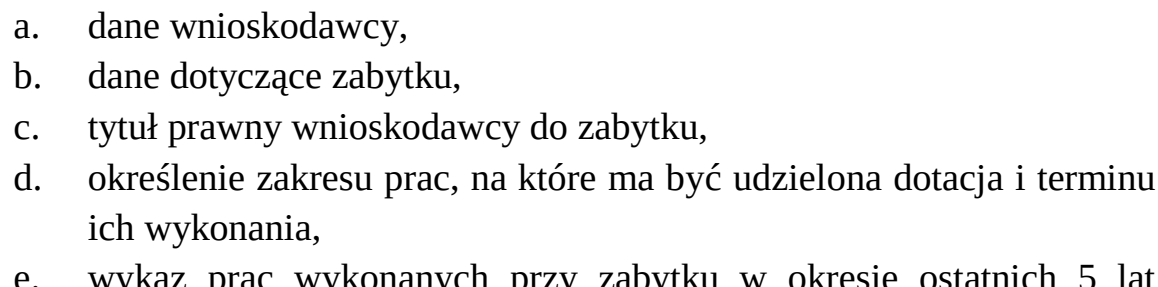

e. wykaz prac wykonanych przy zabytku w okresie ostatnich 5 lat z podaniem wysokości wydatków poniesionych na ich przeprowadzenie oraz uzyskanych środkach publicznych,

f. informację o tym, czy wnioskodawca ubiega się o dotację na prace objęte wnioskiem u innego organu mogącego udzielić dotacji.

Zgodnie z ust. 2 § 7 do wniosku o przyznanie dotacji należy załączyć w szczególności:

a. wypis z właściwego rejestru wskazujący podstawę działalności podmiotu ze wskazaniem osoby lub osób uprawnionych do złożenia wniosku i podpisania umowy,

b. decyzję o wpisie zabytku do rejestru zabytków,

c. dokument potwierdzający posiadanie przez wnioskodawcę tytułu prawnego do zabytku,

d. zalecenia konserwatorskie określające zakres i sposób prowadzenia planowanych przy zabytku prac,

e. kosztorys inwestorski prac zatwierdzony przez wojewódzkiego konserwatora zabytków,

f. pozwolenie na budowę, o ile wymaga tego charakter prowadzonych prac,

g. dokumentację fotograficzną zabytku,

h. oświadczenie, że podatek VAT nie stanowi kosztu u wnioskodawcy (formularz oświadczenia stanowi załącznik do zasad).

Jak stanowi §6 ust. 3 zasad, w przypadku ubiegania się o dotację przez podmiot prowadzący działalność gospodarczą, udzielone dofinansowanie będzie stanowić pomoc de minimis $\mathrm{w}$ rozumieniu rozporządzenia Komisji (WE) nr 1998/2006 z dnia 15 grudnia 2006 r. w sprawie stosowania art. 87 i 88 Traktatu do pomocy de minimis ${ }^{12}$ do czasu obowiązy-

12 Dz.Urz. UE L z dnia 15.12.2006 r. nr 379, poz. 5. 
wania ww. rozporządzenia, tj. do 31 grudnia 2013 r. Według wyżej przywołanego rozrządzenia pomoc de minimis stanowi szczególną kategorię wsparcia udzielanego przez państwo, gdyż uznaje się, że ze względu na swą małą wartość nie powoduje ona zakłócenia konkurencji w wymiarze unijnym. W związku z powyższym nie stanowi ona de facto pomocy publicznej w rozumieniu art. 107 ust. 1 Traktatu o funkcjonowaniu Unii Europejskiej, a w konsekwencji nie podlega obowiązkowi notyfikacji Komisji Europejskiej. Według §6 ust. 4 przy ubieganiu się o pomoc de minimis podmiot starający się o dotację celową przedstawia wraz z wnioskiem:

a. wszystkie zaświadczenia o pomocy de minimis, jakie otrzymał w roku, w którym ubiega się o pomoc oraz w ciągu 2 poprzedzających go lat, albo oświadczenia o wielkości pomocy de minimis otrzymanej w tym okresie, albo oświadczenia o nieotrzymaniu takiej pomocy w tym okresie;

b. informacje zawarte $\mathrm{w}$ rozporządzeniu Rady Ministrów $\mathrm{z}$ dnia 29 marca 2010 r. w sprawie zakresu informacji przedstawianych przez podmiot ubiegający się o pomoc de minimis ${ }^{13}$.

Zarząd Powiatu na podstawie $\S 7$ ust. 4a dokonuje analizy kompletności złożonych wniosków, merytorycznej oraz podmiotowo-przedmiotowej ich zasadności oraz opiniuje zasadność wnioskowanej kwoty dotacji. Zgodnie $\mathrm{z}$ ust. 5 wnioski uznane $\mathrm{w}$ świetle zasad za niekompletne lub nieprawidłowo wypełnione, a także merytorycznie nieuzasadnione, Zarząd Powiatu zwraca wnioskodawcy wraz z uzasadnieniem.

Rada Powiatu na podstawie $\S 8$ ust. 1 przyznaje dotacje konkretnym podmiotom w drodze uchwały uprzednio zaopiniowanej przez komisję rady, do zadań której należą m.in. sprawy z zakresu ochrony zabytków i opieki nad zabytkami. Komisja formułuje swoją opinię na podstawie dokonanej analizy otrzymanych wniosków wraz ze wszystkimi załącznikami. Zgodnie z ust. 2 w uchwale określa się: nazwę wnioskodawcy, któremu udzielono dotacji, nazwę zadania, wykaz prac i robót na wykonanie których przyznano dotację, kwotę przyznanej dotacji.

13 Dz.U. z 2010 r. Nr 53, poz. 311. 
Kryteria, które mają zastosowanie przy opiniowaniu wniosków o dotację, określa §8 ust. 3:

1. znaczenie zabytku dla dziedzictwa kulturowego ze szczególnym uwzględnieniem jego wartości historycznej, naukowej lub artystycznej,

2. dostępność zabytku dla społeczeństwa,

3. stan zagrożenia, w jakim znajduje się zabytek,

4. racjonalne uzasadnienie kosztów realizacji planowanych prac oraz zaangażowanie finansowe podmiotu występującego o dotację,

5. pozyskanie środków finansowych z innych źródeł,

6. wpływ na życie społeczno-gospodarcze.

Na podstawie §8 ust. 4 i 5 wszyscy wnioskodawcy są powiadamiani $\mathrm{w}$ formie pisemnej o przyznaniu lub odmowie przyznania dotacji, natomiast ogłoszenia o przyznanych dotacjach publikowane są w Biuletynie Informacji Publicznej Powiatu Włocławskiego. Zgodnie z §9 ust. 1 zasad uchwała Rady Powiatu określająca beneficjentów dotacji „zabytkowej” stanowi podstawę do zawarcia umowy z wnioskodawcą. Przyznana dotacja może być niższa od wnioskowanej (ust. 2). W takim przypadku wnioskodawca może:

1. odstąpić od zawarcia umowy, powiadamiając o tym pisemnie Zarząd Powiatu w ciągu 14 dni od daty otrzymania informacji o wysokości przyznanej dotacji, lub

2. podjąć się realizacji zadania, zobowiązując się do zachowania deklarowanej we wniosku kwoty środków własnych oraz dokonać korekty zakresu rzeczowego i finansowego zadania, dostosowując je do wysokości otrzymanej dotacji w formie skorygowanego wniosku.

Zgodnie z $\$ 9$ ust. 3 przekazanie dotacji następuje na podstawie umowy, która w szczególności określa:

1. opis prac lub robót i termin ich wykonania,

2. kwotę dotacji oraz termin i tryb jej przekazania,

3. tryb kontroli wykonania umowy,

4. sposób rozliczenia dotacji i sporządzenia sprawozdania,

5. warunki i sposób zwrotu niewykorzystanej dotacji albo dotacji wykorzystanej niezgodnie z przeznaczeniem, 
6. zobowiązanie do przestrzegania przez wnioskodawcę ustawy Prawo zamówień publicznych lub zasad konkurencyjności,

7. zobowiązanie strony do oznakowania przedsięwzięcia zgodnie ze wzorem w celu informowania o finansowaniu lub współfinansowaniu zadania ze środków pochodzących z budżetu powiatu włocławskiego (wzór znaku jest załącznikiem do zasad udzielania dotacji).

Środki na dofinansowanie według §9 ust. 4 przekazuje się na rachunek bankowy wnioskodawcy. Podmiot otrzymujący dotację zobowiązany jest do złożenia sprawozdania merytorycznego i rozliczenia finansowego dotacji w terminie 15 dni od daty zakończenia realizacji zakresu prac (§10).

Zarząd Powiatu na podstawie §11 ust. 1 prowadzi wykaz udzielonych dotacji oraz informuje inne organy uprawnione do udzielania dotacji o dotacjach przyznanych przez Radę Powiatu.

Starosta zgodnie z ust. 2 \$11 przedkłada Zarządowi Powiatu informację o sposobie wykorzystania i rozliczenia dotacji przez podmiot wnioskujący o jej przyznanie.

\section{Dotacje „zabytkowe” w latach 2012-2013}

Na podstawie zasad uchwalonych przez Radę Powiatu we Włocławku dotacje zostały udzielone w latach 2012 i 2013.

W roku 2012 środki finansowe w wysokości 50 tys. zł zostały przyznane Parafii Rzymsko-Katolickiej pw. Św. Stanisława Biskupa w Brześciu Kujawskim na mocy uchwały nr XVII/183/12 Rady Powiatu z dnia 9 listopada 2012 r. w sprawie przyznania w roku 2012 dotacji na prace konserwatorskie, restauratorskie lub roboty budowlane przy zabytkach wpisanych do rejestru zabytków na obszarze powiatu włocławskiego oraz jej wysokości ${ }^{14}$. Rada Powiatu na mocy uchwały nr XV/170/12 z dnia 24 sierpnia 2012 r. zmieniającej uchwałę w sprawie uchwalenia budżetu

14 http://bip.powiat.wloclawski.pl/?app=uchwaly\&nid=12829\&y=2012 (dostęp: 31 października 2013 r.). 
powiatu włocławskiego na 2012 rok $^{15}$ zabezpieczyła środki finansowe w wysokości 50 tys. zł w dziale 921 rozdział 92129 ochrona zabytków i opieka nad zabytkami, §2720 dotacje celowe z budżetu na finansowanie lub dofinansowanie prac remontowych i konserwatorskich obiektów zabytkowych przekazane jednostkom niezaliczanym do sektora finansów publicznych (takim jak: stowarzyszenia, fundacje, pozostałe jednostki spoza sektora finansów publicznych, celem działania których nie jest osiągnięcie zysku). Ponadto w $\$ 2730$ dotacje celowe z budżetu na finansowanie lub dofinansowanie prac remontowych i konserwatorskich obiektów zabytkowych przekazanych jednostkom zaliczanym do sektora finansów publicznych (np. jednostkom budżetowym, uczelniom publicznym, państwowym i samorządowym instytucjom kultury, jednostkom samorządu terytorialnego i ich związkom) została zabezpieczona kwota 10 tys. zł.

Na podstawie uchwały nr XX/220/13 Rady Powiatu z dnia 8 lutego 2013 r. w sprawie przyznania w roku 2013 dotacji na prace konserwatorskie, restauratorskie lub roboty budowlane przy zabytkach wpisanych do rejestru zabytków na obszarze powiatu włocławskiego oraz jej wysokości ${ }^{16}$ środki finansowe w kwocie 40 tys. zł przekazano Parafii Rzymsko-Katolickiej pw. Wniebowzięcia Najświętszej Maryi Panny w Izbicy Kujawskiej na prace konserwatorskie, restauratorskie i roboty budowlane w kaplicy pw. św. Floriana. Rada Powiatu na mocy uchwały nr XIX/208/12 Rady Powiatu z dnia 28 grudnia 2012 r. w sprawie uchwalenia budżetu powiatu włocławskiego na 2013 rok $^{17}$ zabezpieczyła środki finansowe w wysokości 50 tys. zł w dziale 921 rozdział 92129 ochrona zabytków i opieka nad zabytkami, §2720 dotacje celowe z budżetu na finansowanie lub dofinansowanie prac remontowych i konserwatorskich obiektów zabytkowych przekazane jednostkom niezaliczanym do sektora finansów publicznych. Ponadto w \$2730 dotacje celowe z budżetu na finansowanie lub dofinansowanie prac remontowych i konserwatorskich

15 http://bip.powiat.wloclawski.pl/?app=uchwaly\&nid=12584\&y=2012 (dostęp: 31 października 2013 r.).

16 http://bip.powiat.wloclawski.pl/?app=uchwaly\&nid=13201\&y=2013 (dostęp: 31 października 2013 r.).

17 http://bip.powiat.wloclawski.pl/?app=uchwaly\&nid=13040 (dostęp: 31 października 2013 r.). 
obiektów zabytkowych przekazane jednostkom zaliczanym do sektora finansów publicznych została zabezpieczona kwota 10 tys. zł.

W 2013 r., po zmianie zasad udzielania dotacji, Rada Powiatu uchwałą nr XXV/259/13 z dnia 26 sierpnia $2013 \mathrm{r} .{ }^{18}$ przyznała dotacje dla dwóch kolejnych wnioskodawców: Parafii Rzymsko-Katolickiej pw. św. Prokopa w Kłóbce w wysokości 20 tys. zł oraz Parafii RzymskoKatolickiej pw. Św. Stanisława Biskupa w Brześciu Kujawskim w wysokości 20 tys. zł. W celu zabezpieczenia środków na ten cel Rada Powiatu uchwałą nr XXIII/249/13 z dnia 17 czerwca 2013 r. ${ }^{19}$ dokonała kolejnych zmian w budżecie na 2013 rok, polegających na przesunięciu kwoty 10 tys. zł z §2730 do §2720 klasyfikacji budżetowej oraz zwiększenia środków finansowych o kwotę 20 tys. zł z przeznaczeniem na dotacje na prace konserwatorskie, restauratorskie lub roboty budowlane przy zabytkach wpisanych do rejestru zabytków na obszarze powiatu włocławskiego. Środki finansowe pochodziły z rezerwy ogólnej. Decyzja Rady była spowodowana dużym zainteresowaniem podmiotów ubiegających się o dofinansowanie $\mathrm{w}$ formie dotacji. Stąd również zaszła konieczność zmiany Zasad udzielania dotacji w zakresie wprowadzenia dodatkowego terminu ich przyznawania w roku realizacji zadania.

Tabela 1. Dotacje na prace konserwatorskie, restauratorskie lub roboty budowlane przy zabytkach wpisanych do rejestru zabytków na obszarze powiatu włocławskiego w latach 2012-2013

\begin{tabular}{|l|l|l|l|l|}
\hline \multicolumn{1}{|c|}{ Rok } & \multicolumn{1}{|c|}{2012} & \multicolumn{3}{|c|}{2013} \\
\hline $\begin{array}{l}\text { Liczba udzielo- } \\
\text { nych dotacji }\end{array}$ & 1 & \multicolumn{2}{|c|}{3} \\
\hline $\begin{array}{l}\text { Wysokość udzie- } \\
\text { lonej dotacji }\end{array}$ & $50000,00 \mathrm{zł}$ & $40000,00 \mathrm{zł}$ & $20000,00 \mathrm{zł}$ & 20000,00 zł \\
\hline Wnioskodawca & $\begin{array}{l}\text { Parafia Rzym- } \\
\text { sko-Katolicka } \\
\text { pw. Św. Stani- } \\
\text { sława Bpa w } \\
\text { Brześciu Kuj. }\end{array}$ & $\begin{array}{l}\text { Parafia Rzym- } \\
\text { sko-Katolicka } \\
\text { pw. WNMP w } \\
\text { Izbicy Kuj. }\end{array}$ & $\begin{array}{l}\text { Parafia Rzym- } \\
\text { sko-Katolicka } \\
\text { pw. św. Proko- } \\
\text { pa w Kłóbce }\end{array}$ & $\begin{array}{l}\text { Parafia Rzym- } \\
\text { sko-Katolicka } \\
\text { pw. św. Stani- } \\
\text { sława Bpa w } \\
\text { Brześciu Kuj. }\end{array}$ \\
\hline
\end{tabular}

18 http://bip.powiat.wloclawski.pl/?app=uchwaly\&nid=14080\&y=2013 (dostęp: 31 października 2013 r.).

19 http://bip.powiat.wloclawski.pl/?app=uchwaly\&nid=13824\&y=2013 (dostęp: 31 października 2013 r.). 
Dotacje na prace konserwatorskie, restauratorskie lub roboty budowlane...

\begin{tabular}{|c|c|c|c|c|c|}
\hline \multicolumn{2}{|c|}{ Nazwa zabytku } & $\begin{array}{l}\text { Podominikański } \\
\text { Kościół Klasz- } \\
\text { torny pw. św. } \\
\text { Michała Archa- } \\
\text { nioła w Brześciu } \\
\text { Kuj. }\end{array}$ & $\begin{array}{l}\text { Kaplica pw. } \\
\text { św. Floriana } \\
\text { w Sokołowie } \\
\text { (Pustynia), } \\
\text { gmina Izbica } \\
\text { Kuj. }\end{array}$ & $\begin{array}{l}\text { Ołtarz boczny } \\
\text { z elementami } \\
\text { z XVII, XVIII } \\
\text { i XIX w. oraz } \\
\text { dwoma obra- } \\
\text { zami olejnymi } \\
\text { na płótnie z } \\
\text { XVIII, XIX w. }\end{array}$ & $\begin{array}{l}\text { Podominikań- } \\
\text { ski Kościół } \\
\text { Klasztorny } \\
\text { pw. Michała } \\
\text { Archanioła w } \\
\text { Brześciu Kuj. }\end{array}$ \\
\hline \multicolumn{2}{|c|}{$\begin{array}{l}\text { Wysokość wnio- } \\
\text { skowanej dotacji }\end{array}$} & 55 000,00 zł & $50000,00 \mathrm{zł}$ & 20 286,90 zł & 25 000,00 zł \\
\hline \multicolumn{2}{|c|}{$\begin{array}{l}\text { Koszt prac obję- } \\
\text { tych wnioskiem }\end{array}$} & 250 850,08 zł & 263 198,29 zł & $67623,00 \mathrm{zł}$ & 66 484,78 zł \\
\hline \multirow{2}{*}{ 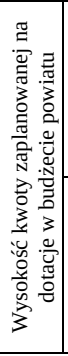 } & $\begin{array}{l}\text { Jednostki } \\
\text { niezaliczane } \\
\text { do sektora } \\
\text { finansów } \\
\text { publicznych }\end{array}$ & $50000,00 \mathrm{zł}$ & \multicolumn{3}{|c|}{$\begin{array}{l}80 \text { 000,00 zł (kwota uległa zwiększeniu w wyniku } \\
\text { zmian dokonanych w budżecie powiatu uchwalo- } \\
\text { nym na } 2013 \text { r.) }\end{array}$} \\
\hline & $\begin{array}{l}\text { Jednostki } \\
\text { zaliczane do } \\
\text { sektora } \\
\text { finansów } \\
\text { publicznych }\end{array}$ & $10000,00 \mathrm{zł}$ & \multicolumn{3}{|c|}{$\begin{array}{l}10 \text { 000,00 zł - środki zostały przeniesione między } \\
\text { paragrafami na dotacje dla jednostek niezalicza- } \\
\text { nych do sektora finansów publicznych na podsta- } \\
\text { wie uchwały zmieniającej. }\end{array}$} \\
\hline \multicolumn{2}{|c|}{$\begin{array}{l}\text { Udział dotacji w } \\
\text { wartości zadania }\end{array}$} & $20 \%$ & $15,2 \%$ & $29,58 \%$ & $30,08 \%$ \\
\hline
\end{tabular}

Źródło: Opracowanie własne na podstawie: uchwał w sprawie przyznania dotacji na prace konserwatorskie, restauratorskie lub roboty budowlane przy zabytkach wpisanych do rejestru zabytków na obszarze powiatu włocławskiego oraz jej wysokości w latach 2012-2013, uchwały zmieniającej uchwałę w sprawie uchwalenia budżetu powiatu włocławskiego na 2012 rok, uchwały w sprawie uchwalenia budżetu na rok 2013 i uchwał zmieniających oraz składanych wniosków o przyznanie dotacji.

\section{Wnioski}

Na podstawie przedstawionych danych można zauważyć, że wnioski o przyznanie dotacji składają wyłącznie parafie z terenu powiatu włocławskiego. Pojawia się pytanie: dlaczego? Z pewnością powodem nie jest brak obiektów wpisanych do rejestru zabytków, które należą do jednostek sektora finansów publicznych. Najbardziej jest realne powody to brak środków na wkład własny, a także - być może - brak wiedzy w tym sektorze na temat możliwości ubiegania się o takie dotacje. Innym powodem mogą być zbyt skomplikowane czynności związane ze sporządze- 
niem odpowiedniego wniosku, które już na początku zniechęcają podmioty do jego złożenia, co powoduje brak motywacji do opracowania wniosku o udzielenie dotacji i zebrania odpowiedniej dokumentacji.

Z danych zawartych w przedstawionej tabeli wynika, że z roku na rok zwiększa się jednak zainteresowanie dotacjami, o czym świadczy fakt, że zwiększyła się liczba podmiotów składających wnioski. Liczba udzielanych dotacji w roku 2013 w porównaniu do roku 2012 zwiększyła się trzykrotnie. W związku z większą liczbą składanych wniosków wysokość udzielanej dotacji wykazuje tendencję spadkową. Jak wynika z danych zawartych w ostatnim wierszu Tabeli 1, udział dotacji w wartości zadania w czasie dwóch ostatnich lat wzrósł o kilka punktów procentowych. Rada Powiatu, widząc potrzeby wnioskodawców, dokonywała zmian w uchwale budżetowej, aby umożliwić udzielenie dotacji w wyższej wysokości i większej liczbie podmiotów. Należy zauważyć, że zakres prac, które mają być sfinansowane ze środków pochodzących z dotacji, obejmuje zazwyczaj remonty konstrukcji dachów kościołów.

Rok 2013 jest dopiero drugim rokiem funkcjonowania uchwały w sprawie zasad udzielania dotacji na zabytki w powiecie włocławskim. W roku 2014 planowane jest zabezpieczenie w budżecie kwoty 80 tys. zł na ten cel, istnieje więc możliwość, że z upływem czasu zwiększy się liczba składanych wniosków i będą one wpływały od zróżnicowanych podmiotów. Zarząd Powiatu, widząc zwiększające się zainteresowanie korzystaniem z tego typu dotacji, proponuje w uchwale Zarządu Powiatu nr 378/13 z dnia 15 listopada 2013 r. w sprawie przyjęcia projektu budżetu powiatu włocławskiego na 2014 rok oraz projektu Wieloletniej Prognozy Finansowej Powiatu Włocławskiego na lata 2015-2022 ${ }^{20}$ zwiększenie środków finansowych na ten cel do wysokości 80 tys. zł.

Sądzę, że dotacje „zabytkowe” są bardzo ważnym wydatkiem ponoszonym przez powiat włocławski. Są to środki finansowe pozwalające na remont i konserwację naszego dziedzictwa kulturowego, które stanowi wizytówkę regionu kujawsko-pomorskiego i atrakcję turystyczną. Warto czynić starania, aby takie obiekty mogły odzyskać dawną świetność.

20 http://bip.powiat.wloclawski.pl/?app=uchwaly\&nid=14502\&y=2013 (dostęp: 31 października 2013 r.). 


\section{Bibliografia:}

Kosikowski C., Ruśkowski E. (red.), Finanse publiczne i prawo finansowe, Wolters Kluwer, Warszawa 2008.

Ruśkowski E., Salachna J.M. (red.), Nowa ustawa o finansach publicznych wraz z ustawq wprowadzajqca. Komentarz praktyczny, ODDK, Gdańsk 2010.

Salachna J.M., Granice samodzielności legislacyjnej jednostek samorzq̨du terytorialnego. Studium prawnofinansowe na gruncie ustrojowym, ODDK, Gdańsk 2012.

Tyniewicki M., Kompetencje organów jednostek samorzq̨du terytorialnego w zakresie ustanawiania i udzielania dotacji celowych [w:] A. Borodo (red.), Dotacje i subwencje w systemie finansowym samorzqdu terytorialnego, TNOiK, Toruń 2013.

Wójtowicz W. (red.), Zarys finansów publicznych i prawa finansowego, Wolters Kluwer, Warszawa 2008. 